\title{
Understanding the Performance of Domestic Biodigesters in Bangladesh: A Study from Household Level Survey
}

\author{
Samira Salam ${ }^{1}$, Rehena Parveen ${ }^{2}$, S.M. Nasim Azad ${ }^{2}$, Md. Abdus Salam ${ }^{3}$ \\ ${ }^{1}$ Department of Basic Sciences, Primeasia University, Banani, Dhaka, Bangladesh \\ ${ }^{2}$ Department of Statistics, Bangabandhu Sheikh Mujibur Rahman Science and Technology University, Gopalgonj, \\ Bangladesh \\ ${ }^{3}$ Department of Statistics, Jahangirnagar University, Savar, Dhaka, Bangladesh \\ Correspondence: Md. Abdus Salam, Department of Statistics, Jahangirnagar University, Savar, Dhaka 1342, \\ Bangladesh.
}

Received: May 19, 2020

Accepted: June 12, 2020

Online Published: June 29, 2020

doi:10.11114/bms.v6i2.4869

URL: https://doi.org/10.11114/bms.v6i2.4869

\begin{abstract}
Biogas can be an important alternative energy source for the sustainable development of the energy sector. To understand the performance of the family-size biodigester in Bangladesh, a household level survey on randomly selected 360 biodigester adopters was conducted. It is evident from the study that adoption of biodigester at the household level is economically and environmentally viable. Most of the biodigesters were constructed for single household and production of biogas was sufficient for cooking for single household. About 35\% of biodigesters generated surplus gas from which they earned money by selling the surplus gas. About $91 \%$ of the biodigesters were feed with cow dung, one of the optimal biogases producing substrates, which has easy access in their own households. The factor analysis suggests that the most important factors to make biodigester economically viable are: capacity of biodigester, availability of substrates, amount of investment for biodigester, and economic benefits derived from biodigester.
\end{abstract}

Keywords: biodigester, biogas, feedstocks, economic benefits, sustainable development

\section{Introduction}

In most developing countries, cooking is a dirty and time-consuming job that involves burning solid fuels to produce fire. Worldwide, approximately 3 billion people are burning solid fuels, including biomass, agricultural residues and charcoal, for their daily cooking (Venkata, Michael, Sumi, \& Srilata, 2015). Solid wood fuels used for cooking and heating, represent approximately 55\% of global wood harvest and 9\% of primary energy (UN FAO, 2013; REN21 Secretariat, 2013). However, about 50\% of the wood fuel harvest is unsustainable (Bailis, Drigo, Ghilardi,\& Masera, 2015). Cooking over a 3-stone fire in a home is equivalent to burning 400 cigarettes in an hour that release toxic smoke and emissions which mostly affect women and children (EFC, 2012). A study by Global Health revealed that inefficient cook stoves to be the largest environmental threat (GEC, 2012). Worldwide about 70,000 people die per year because of household air pollution (IHME, 2017). Thus, cooking by solid fuels is a challenge as inefficient systems of cooking have a major impact on health, environment and economy (UN, 2015a). The overdependence on solid fuels as primary source of cooking fuel has led to global climate change, and environmental pollution, and thus leading to human health problems (Otun, Ojo, Ajibade, \& Babatola, 2015). The continuous burning of solid fuels leads to long term health problems, largely among the women and children of the households. In addition to major contribution to climate change, environmental pollution and health, global depletion of solid fuels has led to the search for alternative sources of energy. Improvement of renewable and sustainable energy source is the best strategy to meet the country's energy demand (Donald, 1998; Das, Sahoo, \& Rana, 2018).

Biogas is an alternative promising substitute to solid fuel and capable of replacing current energy supply and can only be considered as the best for meeting the demand and assurance of imminent energy in a sustainable manner (Corro, Paniagua, Pal, Banelos, \& Rosas, 2013; Mel, Yong, Avicenna, Ihsan \& Setyobudi, 2015). Biogas is assumed a green sustainable gas produced by the anaerobic digestion (AD) of organic agricultural waste, manure, municipal waste, plant materials, sewage, green waste or food waste. It can be produced from locally available raw materials and recycled 
waste and is agreed environmentally friendly and neutralizing greenhouse effects and thus contributed climate change mitigation (Clements, Trimborn, Welland, \& Amon, 2006; McCarl, 2010; Zahariev, Penkov, \& Aladjadjiyan, 214; Das et al., 2018; Hosseinpour, Hosseini, Mehdipour, Hemmasi, \& Ali, 2020). This process produces gases which contains roughly 50-70\% methane $\left(\mathrm{CH}_{4}\right), 30-40 \%$ carbon dioxide $\left(\mathrm{CO}_{2}\right)$, and trace amounts of other gases (USDA, 2014). It has positive environmental impact due to the reduction of $\mathrm{CO}_{2}$ and $\mathrm{CH}_{4}$ )-the cause of global warming (Uzodinma, Ofoefule, Eze, \& Onwuka, 2007).

Biogas energy is currently used in the developing world, especially in Asia to meet energy demand by low-income households and prevent the environmental and health effects of solid fuel use (Gautam, Baral, \& Herat, 2009). It is an alternative choice for households that have access to sufficient organic feedstocks suitable for biogas production (IRENA, 2017). About 50 million biogas digesters have been installed to generate gas for cooking worldwide (Clemens, Bailis, Nyambane,. \& Ndung'u, 2018). The majority of the biogas digesters are installed in Asia, particularly in China (Chen, Zhao, Ren, \& Wang, 2012; Putti, Tsan, Mehta, \& Kammila, 2015; Wang et al., 2016) and India (IRENA, 2017; Putti et al. 2015) Approximately, 300,000 biodigesters are installed in Nepal (Bajgain \& Shakya, 2005, Saroj, 2012) and another 300,000 in Vietnam, Bangladesh, Cambodia, Indonesia, and Pakistan (IRENA, 2017; Clemens et al., 2018).

Being a densely populated country having limited natural resources, Bangladesh has been severely suffering from the energy crisis since past few decades. Bangladesh is one of the fastest growing economies in the Southern-Asia, with 64\% of the total population are living in rural areas (Suntrace, 2018). More than $90 \%$ of the rural people depend on biomass fuels to meet the energy needs for cooking, still only $62.4 \%$ of these people have access to electricity (Kabir, Palash, \& Bauer, 2012; Rahman, Melville, Edwards, Fulford,. \& Thwala, 2019). An uninterrupted energy supply is key to ensuring sustainable economic growth within a nation like Bangladesh, where recent economic growth has contributed to the public's insatiable demand for energy (Hasan \& Ammenberg, 2019). Households in Bangladesh rely heavily on solid biomass for cooking; large majorities use wood and dry cow dung as their primary cooking fuels (Samira, Parveen, Salam, \& Azad, 2020). This is particularly true in rural areas, where over $82 \%$ of households report using biomass fuels as primary energy (WHO, 2016). The disadvantages of the biomass fuels are many: (i) they are inefficient energy carries and the heat release rate is difficult to control; (ii) they release harmful gases; and (iii) the current rate of extraction is unsustainable (Parawira, 2009). Moreover, regeneration limit of biomass fuels has already been beyond the population growth in Bangladesh (Goffar, 2007; Kabir et al., 2012). Fuels like LPG burned in advanced stoves emit less pollution than unprocessed wood or cow dung. But LPG is incredibly expensive and beyond the capacity for most of the rural households. Clean fuels like ethanol, advanced gasifier stoves, and solar stoves are almost absent. Due to dearth of fossil fuel reserve, the only way to minimize the supply-demand gaps in the energy sector is moving towards the alternative renewable energy sources. The programs of generating alternative energy resources with low carbon emission from both the government and the private investors are still on the early stages. But there have been some notable achievements as some rural people by their own efforts have started generation of biogas energy at household level. Thus, biogas can be a substitute of traditional solid fuels and can meet the rural energy demand in Bangladesh.

If the supply of energy is not increased according to its demand, there would be serious adverse consequences on the nation's economic development. As a result, nation would suffer from the assertion of energy security for future generation. The energy growth programs in a developing country like Bangladesh are heavily dependent on the sustaining relationship between energy consumption and economic growth, energy consumption and Human Development Index, biomass fuel consumption and economic growth and different energy sources providing world energy demand. A long-term effective, comprehensive and integrated energy policy should be formulated in order to ensure energy security over short, medium and long terms for the country. The policy should ensure tapping of all possible sources of energy, adequate supply and equitable access to renewable energy for all segments of the society. Due emphasis must be given on the usage of the renewable energy sources and extensive research and development programs should be conducted for the further development of renewable energy technologies.

\subsection{Statement of the Research Problem and Objectives}

Although there has been extensive academic research into the prospects and constraints of domestic biogas technology in the developing world (Van Nes \& Nhete, 2007; Gautam et al., 2009; Greben \& Oelofse, 2009, Parawira, 2009; Bond \& Tepleton, 2011; Amigun, Parawira, Musango, Aboyade, \& Badmos, 2012; Ghimire, 2013; Surendra, Takara, Hasimoto, \& Khanal, 2014; Sunset, \& Gerrit, 2017; Rahman, et al., 2019; Hasan \& Ammenberg, 2019), very few research is available in the context of Bangladesh. Biogas programs in Bangladesh is still very limited. Most of the literature about biogas programs in Bangladesh discussed its potential and feasibility of biogas programs (Samira et al. 2020; Nes, Boers, \& Khurshed-Ul-Islam,2005; Nes, \& Nhete, 2007; Kabir et al. 2012; Salma, Rahman, \& Yousuf, 2014; Shahrul, Hassan, Mamun, \& Malek, 2007). But evaluation of the performance of the existing biodigesters is essential to make the biogas program successful and sustainable. This study attempts to evaluate the performance of the existing biodigesters in Bangladesh. The $7^{\text {th }}$ Sustainable Development Goal (SDG) includes the target of ensuring universal 
access to affordable, reliable and modern energy services by 2030 (UN, 2015b). Another important challenge is the security of energy supply. To achieve these challenging goals, understanding the present status of affordable, reliable and clean energy that suit the economic and geographical conditions is needed. The objectives of this desktop study were to investigate the performance, the economic and environmental benefits associated with installation of biodigesters in Bangladesh.

\subsection{Data Collection and Methodology}

This study was based on cross-section data collected using four-stage cluster sampling. At the first stage, 20 districts from 64 districts of Bangladesh were selected randomly. At the second stage, one upazilla from each selected district were randomly selected. At the third stage, two unions from each selected upazilla were selected randomly yielding a total of 40 unions. As there is no sampling frame of biodigester adaptors and the biodigester adaptors are very limited in number, all the biodigester adaptors of the selected unions were detected using snowball sampling technique and interviewed by a structured questionnaire. A total of 360 biodigester adaptors were identified and each of selected adaptor was interviewed by a structured questionnaire. The survey was carried out in January 2017. The first digester was installed in 2006, but almost $98 \%$ of the biodigesters were installed before January 2015, so most adaptors possessed more than two years of experience in biodigester use. Statistical software, SPSS was used to analyzed the data. Various statistical tools, such as summary measures and factor analysis were carried out to meet the objectives of the study.

\section{Results and Discussion}

\subsection{Background Characteristics of the Respondents}

Respondents' background characteristics are associated with the adoption of biogas technologies in rural areas. Thus, this subsection summarizes background characteristics of the biodigester adaptors and is presented in Table 1. The tabulation of biodigester adaptors by religion indicates a majority were Muslim adherents (about 94\%) and the rest were Hindu adherents. About $42 \%$ of the biodigester adaptors belonged to age below 40 years, about $32 \%$ of the biodigester adaptors were aged 40-49 years. Family size is an important stimulus for the adoption of biodigester because cost of cooking fuels for greater family size might be higher than for smaller family size. It is seen from the table that family size of about 53\% of the biodigester adaptors were 5-6 and family size of about $19 \%$ of the biodigester adaptors were 7-8. Education is also an important catalyst for the adoption biodigester. More than $90 \%$ of the biodigester adaptors completed secondary or more level of education and about $23 \%$ of the biodigester adapters were completed graduate degrees. Occupation is also an important factor for adopting biodigester. It is seen from Table 4.1 that highest proportion (about 46\%) of biodigester adaptors were businessmen, about $31 \%$ were farmers and about $20 \%$ were servicemen. Family income is also one of the most important factors for influencing people to adopt biogas digester. Table 4.2 shows that per month family income of about $16 \%$ of the biodigester adopters was more than BDT 40,000 and per month family income of about $61 \%$ of the biodigester adopters was more than BDT 20,000. 
Table 1. Background characteristics of the biodigester adopters

\begin{tabular}{|c|c|}
\hline Characteristics & Percent \\
\hline \multicolumn{2}{|l|}{ Religion } \\
\hline Muslim & 94.3 \\
\hline Hindu & 5.7 \\
\hline \multicolumn{2}{|l|}{ Age } \\
\hline$<30$ & 16.0 \\
\hline $30-39$ & 25.8 \\
\hline $40-49$ & 32.0 \\
\hline $50-59$ & 20.5 \\
\hline$\geq 60$ & 5.8 \\
\hline \multicolumn{2}{|l|}{ Family size } \\
\hline$\leq 4$ & 23.8 \\
\hline $5-6$ & 52.5 \\
\hline $7-8$ & 19.3 \\
\hline$>8$ & 4.5 \\
\hline \multicolumn{2}{|l|}{ Education } \\
\hline Primary & 7.8 \\
\hline Secondary & 49.8 \\
\hline Higher Secondary & 19.5 \\
\hline Graduate & 18.5 \\
\hline Post-graduate & 4.5 \\
\hline \multicolumn{2}{|l|}{ Occupation } \\
\hline Agriculture & 30.5 \\
\hline Service & 19.8 \\
\hline Business & 45.8 \\
\hline Foreign Employment & 1.8 \\
\hline Others & 2.3 \\
\hline \multicolumn{2}{|c|}{ Per month family income (in BDT)* } \\
\hline$<5000$ & 4.4 \\
\hline $5000-9999$ & 5.0 \\
\hline 10000-19999 & 29.5 \\
\hline 20000-29999 & 30.5 \\
\hline 30000-39999 & 14.8 \\
\hline 40000-49999 & 4.8 \\
\hline$\geq 50000$ & 11.0 \\
\hline Number of adaptors & 360 \\
\hline
\end{tabular}

\subsection{Types of Biodigester}

Three types of domestic biodigester are popular in developing countries: (i) Chinese fixed dome, (ii) Indian floating drum and (iii) Taiwanese plastic tubular. These are small $\left(5-10 \mathrm{~m}^{3}\right)$ and mostly used to meet household energy demand for cooking and lighting. The Chinese fixed dome digester is often the design of choice because of its reliability, low maintenance requirements and long lifetime (Parawira, 2009). About $94 \%$ of the biodigesters in the study areas were family-sized constructed for domestic use and only $6 \%$ of the biogas digesters were constructed jointly (Table 2). About $1.5-2.4 \mathrm{~m}^{3}$ /day of biogas is considered sufficient to supply cooking requirements for a family of five (Bond \& Templeton, 2011). In the study area, about $43 \%$ of the biodigesters generated less than $3 \mathrm{~m}^{3}$ of gas per day and about $50 \%$ of the biodigesters generated $3-6 \mathrm{~m}^{3} /$ day. About $73 \%$ of the biodigesters supplied biogas to single cookstove and about $19 \%$ of the biodigesters supplied gas to 2-3 cookstoves. 
Table 2. Percent distribution of biodigester adopters according to the type of biodigester type

\begin{tabular}{lcc}
\hline Characteristics of biodigester & Number of Adopter & Percent \\
Digester Type & 340 & \\
Single & 20 & 94.0 \\
Joint & 360 & 6.0 \\
Total & & 100 \\
Digester size (in $\boldsymbol{m}^{\mathbf{3}}$ )/day & 156 & \\
$<3$ & 179 & 43.3 \\
3 to less than 6 & 25 & 49.7 \\
6 and above & 360 & 7.0 \\
Total & & 100 \\
No. of cook stoves per digester & 263 & \\
1 & 69 & 73.1 \\
2-3 & 28 & 19.2 \\
4 and more & 360 & 7.0 \\
Total & & 100 \\
\hline
\end{tabular}

\subsection{Reasons for Installation of Biodigester}

Biogas generation is one of the most promising solutions for organic waste management due to a renewable energy source, less production cost and low production of residual waste (Kiran, Trzcinsk, Ng, \& Liu, 2014). In addition, the digestate produced by the $\mathrm{AD}$ is a nutrient-rich product that could be used as a soil conditioner and organic fertilizer. The production of biogas through $\mathrm{AD}$ offers significant advantages over other forms of bioenergy production. It has been evaluated as one of the most energy-efficient and environmentally beneficial technology for energy production (Weiland, 2010). It can drastically reduce greenhouse gases emissions compared to fossil fuels by utilizing locally available resources. In spite of its versatile benefits, adoption of biodigester and use of biogas depend on the attitude of the biodigester adopters towards biogas. The study results show that (in Table 3) biodigester adopters were interested to install biodigester because of availability of feedstocks in their own farms (about 90\%), environmentally friendly (about $79 \%$ ), and financially sound technology (about 86\%). About $88 \%$ of the biodigester adopters were satisfied with the performance of their biodigesters. These results clearly indicate that Bangladesh contain congenial environment for adopting biodigester technology

Table 3. Percent distribution of biodigester adopters according to reasons of adapting biodigester

\begin{tabular}{lc}
\hline Reasons for adopting biodigester & Percent* \\
Feedstocks are available in own household & 89.5 \\
Biogas use is environmentally friendly & 78.7 \\
Biogas is financially viable & 85.9 \\
Due to scarcity of solid fuels & 67.8 \\
Government and non-government agencies inspired & 17.8 \\
Others & 7.1 \\
Whether satisfied with the performance of biodigester & 88.1 \\
Satisfied & 11.9 \\
Did not satisfy & $\mathbf{3 6 0}$ \\
Total number of adopters &
\end{tabular}

\subsection{Economy of Biodigester}

The economy of biogas plant is characterized by initial investment, couple of operation and maintenance cost, mostly practice free raw materials (animal dung, poultry litter, households' solid wastes etc.) and finally income generate from the production of biogas. Other external values such as production of biofertilizer, reduction of $\mathrm{CO}_{2}$ emission, reduction of health cost, decrease time for cooking and for collecting cooking fuels would be added. In each of these cases, the financial feasibility of the facility depends largely on whether the outputs in form of gas and slurry can substitute for costly fuels, fertilizer, or feed that were previously purchased while, at the same time, abating pollution (Amigun, et al. 2007). 


\subsection{Initial Investment}

One of the major constraints for domestic biodigester adoption is high installation, operating and maintenance costs, which puts it out of financial reach of many rural households (Surendra et al., 2014). Because of high upfront cost, it becomes difficult for most of the farmers to invest such amount initially. Adoption of domestic biodigester also depends on program strategy. Household level adoption can be enhanced by an integrated program approach, including technology standardization, quality control, and integrated farming using biogas and bio-slurry (Mwirigi et al. 2014). Although initial investment for the construction of biodigester is higher compared to traditional fossil fuels, but viewed over time, biogas becomes economically worthwhile considering all externalities (environmental and health benefits, employment generation etc.) and when lower operating costs are taken into account (Bahauddin \& Salauddin, 2012).

Biodigesters in Bangladesh, in majority of the cases, are financed in two ways - a flat rate subsidy from the government on the investment cost and cash contribution from respective plant owners to fill gap. The subsidy provided by the government is insufficient to meet the total cost of installation and a gap exists which the farmers must bridge. This gap is either filled by cash of their own or by credit received from financing institutions on some pre-defined terms and conditions. Total investment cost of biodigesters from adopters' side ranged from BDT 5,000 for biodigesters having capacity less than $3 \mathrm{~m}^{3} /$ day to BDT 240,000 for biodigesters of capacity $12 \mathrm{~m}^{3} /$ day or more (Table 4 ). The average construction cost of about $43 \%$ of the biodigesters having capacity of less than $3 \mathrm{~m}^{3} /$ day was BDT 27,560 . The average construction cost of about $50 \%$ of the biodigesters having capacity of $3-6 \mathrm{~m}^{3} /$ day was BDT40,222. On an average, cost for installation of a biodigester was BDT 35,111.

Table 4. Percent distribution of adopters according to the average initial cost for construction of biodigester

\begin{tabular}{ccccc}
\hline Digester size (in $\mathbf{~ m}^{\mathbf{3}}$ ) & Average cost (in BDT) & Number (Percent) & Minimum & Maximum \\
$<3$ & 27,560 & $156(43.3)$ & 5,000 & 60,000 \\
$3-6$ & 40,222 & $179(49.7)$ & 7,000 & 80,000 \\
$6-9$ & 57,900 & $10(2.7)$ & 28,000 & 120,000 \\
$9-12$ & 102,500 & $5(1.4)$ & 37,500 & 175,000 \\
12 and above & 122,500 & $10(2.7)$ & 60,000 & 240,000 \\
Total & 38,377 & $360(100)$ & & \\
\hline
\end{tabular}

The cost for installation of biodigester was reasonable and farmers could easily afford this amount. According to about 98\% of the biodigester adaptors, installation cost of biodigester in Bangladesh was reasonable or cheap (Table 5). The cost for construction of about $97 \%$ of the biodigester was cash contribution of the respective biodigester adopters and only $7 \%$ of the biodigester adopters received credit from financial institution. Annual operation and maintenance costs for biodigesters were related to repairing, maintenance and replacement costs (Kandapal, Joshi, \& Singh, 1991). In about $81 \%$ of the biodigesters, operation and maintenance costs were not needed because the family members operated and maintained the biodigesters. Annual operation and maintenance costs were less than BDT 1000 for about $8 \%$ biogas digesters and more than BDT 3000 for about $6 \%$ of the biogas digesters. Monthly cost of biogas for cooking per cookstove was less than BDT 300 for about $74 \%$ of the households and monthly cost for cooking per cookstove was BDT 600 or more for about $17.2 \%$ households. At present, cooking cost for natural gas per cookstove is BDT 975 and average cooking cost for solid fuels per household is BDT 1060 (Samira et al., 2020) indicating that cost for cooking by using biogas is considerably less than for cooking by using natural gas or biomass fuels.

Table 5. Initial invest for the construction of biogas digesters

\begin{tabular}{lc}
\hline Particulars about investment & Percent \\
Whether installation cost is low-cost or expensive \\
Low-cost & 98.0 \\
Expensive & 2.0 \\
Source of investment & \\
Own savings & 93.0 \\
Loan & 7.0 \\
Annual operation and maintenance cost (in BDT) \\
No cost & 81.4 \\
$<1000$ & 7.5 \\
$1000 \sim 3000$ & 4.8 \\
$>3000$ & 6.4 \\
Monthly cost for cooking per household (in BDT) \\
$<300$ \\
$300-599$ & 74.0 \\
$\geq 600$ & 5.8 \\
Total & 17.2 \\
\hline
\end{tabular}




\subsection{Feedstock for Biodigester}

The cost and availability of feedstock significantly affect the price of biofuels. A wide range of agricultural crops, residues, manure, and organic wastes are potentially available for use as feedstocks of AD in agricultural households. If biodegradable wastes are easily available as feedstocks, the benefits in dealing with the biodegradable waste could be twofold: (i) economic value of biogas and its digestate; and (ii) environmental cost avoided in some other ways such disposal in landfill (Jones, 2010). However, the economic benefits of outputs may become low if the feedstock are costly such as transport and storage or have to be purchased. Theoretical any biodegradable biomass can be used as feedstock for biogas production. However, potential of biodegradable biomass to generate biogas through AD varies in terms of $\mathrm{C} / \mathrm{N}$ ratios. Biomass with a $\mathrm{C} / \mathrm{N}$ ratio between 20 to 30 has been reported to produce optimal biogas composition (FAO, 1996; das Neves, Converti, \& Penna, 2009; Sagagi, Garbu, \& Usman, 2009). Animal manure (e.g. pig, sheep, and cattle dung) have a higher $\mathrm{C} / \mathrm{N}$ ratio of $18-30$, leaves animal manure are suitable substrates for $\mathrm{AD}$ giving high biogas yields and could provide additional benefits to farmers. In the study area, about $91 \%$ of the biodigester adopters feed with cow dung and about $9 \%$ of the biodigester adopters feed with poultry litter for biogas generation (Table 6). It has been realized that co-digestion can improve biogas production and stability (Karki, Gautam, \& Karki, 1994; Risberg, Sun, Levén, Horn, \& Achnürer, 2013; Moustakasa, Rehanb, Loizidoua, Nizamic, \& Naqvi, 2020; $\mathrm{Li}$ et al. 2020). Organic kitchen wastes co-digested with cattle manure improves the biogas production potential as compared to cattle manure alone (Otun et al., 2015; Abebe, 2017). Consequently, costs for biogas generation by using cow dung or poultry dropping alone are not favorable due to their relatively low biogas yield in comparison with co-digestion with more biodegradable wastes such as kitchen wastes (Moller, Sommer, \& Ahring, 2004; Aragaw, Andargie, \& Gessesse, 2013). The tasks of collecting, stirring and feeding the substrates into the biodigester were largely performed by households' members of the biogas diester adaptors. Almost all the biogas diesters are family size and are situated near the cattle and poultry shed from where substrates are collected. Availability and easy access to feedstocks for biogas generation is one of important catalysts for sustainable generation of biogas for domestic biogas generation in Bangladesh.

Table 6. Percent distribution of biogas diesters according to feed substrate

\begin{tabular}{lc}
\hline Feed substrate & Percent \\
Types of substrate & \\
Cow dung & 90.8 \\
Poultry droppings & 8.9 \\
Others & 0.3 \\
Source of collection of substrates & \\
Own farmhouse & 92.5 \\
Purchase & 1.7 \\
Partially purchase and partially from own farmhouse & 5.6 \\
Total number of adopters & 360 \\
\hline
\end{tabular}

\subsection{Benefits Derived from Biodigesters}

Quantification of benefits from biodigester is crucial in order to assess the success and sustainability of the biodigester program. Benefits from biodigester can be classified into two categories: monetary and environmental. Family size biodigesters are usually constructed for household use only. In the study area, $65 \%$ of the biogas digesters generated biogas only to meet the need for cooking of adopter's family. Generated biogas from rest of the biodigesters was used both for meeting cooking needs of own family and the surplus biogas was sold in the neighbor households. About $13 \%$ of the biodigester adaptors earned less than BDT 600 per month and about 7\% of the biodigester adopters earned BDT 2000 or more from selling surplus biogas (Table 7). Bio slurry is the biproduct of biogas generation. About $73 \%$ of the biogas digester adopters used bio-slurry for use of own agricultural field as fertilizer. About $11 \%$ of the biodigester adopters sold bio-slurry of BDT 5000 10000 per year after meeting the needs of own agricultural field.

Furthermore, the bio-digester is also thought to improve the environment-indoors and outdoors. The indoors environment is enhanced by reduction in the incidents of illness from burning coal, and firewood, and outdoors by reduction in carbon dioxide (CO2) and Sulphur dioxide (SO2) emissions (Pei-dong, Guomei, \& Gang, 2007). Research investigation proved lower greenhouse gas (GHG) emissions from biofuels in comparison to conventional fossil fuels and biomass fuels (Huang, Khanna, Onal, \& Chen, 2013; Silva-Martínez, Sanches-Pereira, Ortiz, Galindo, Coelho, 2020). Before installation of biogas digester, a household typically used firewood, and stalk and straw for cooking purposes. The main benefits incurred from a biogas in relation to household are replacement of commercial fuels by biogas, the reduction in the time needed to collect firewood, and since fertilizer can be replaced by the residue of biogas 
production, a reduction of cost the costs these products. Moreover, growing biofuel production would reduce the cost of conventional fuels by reducing the dependency on petroleum fuel. Thus, biogas generation through AD provides a valuable gas for cooking, better livelihoods in rural areas through health benefit, income generation from surplus time and selling surplus gas after consumption, earning foreign currency from carbon trading etc. (Von EiJi, 2012; Walekhwa, Mugisha, \& Drake, 2009; Jabeen et al., 2020).

Table 7. Percent distribution of digesters according to amount of money earned after using biogas for their own cooking

\begin{tabular}{lc}
\hline Monthly income from biogas (in BDT) & Percent \\
Use only for household cooking & 65.0 \\
$<600$ & 13.3 \\
$600 \sim 900$ & 3.1 \\
$900 \sim 1200$ & 7.0 \\
$1200 \sim 2000$ & 4.9 \\
2000 and more & 6.7 \\
Annual income from bio-slurry (in & \\
BDT) & \\
Use only for own farm & 73.3 \\
$<5000$ & 6.1 \\
5000 10,000 & 11.1 \\
$>10,000$ & 9.5 \\
Total number of adopters & 360 \\
\hline
\end{tabular}

\subsection{Influencing Factors for Economic Viability of Biodigester}

A factor analysis was performed to identify the influencing factors for economic benefits from biodigester. Factor analysis is a generic term for statistical techniques concerned with the reduction of a set of observable variables in terms of a small number of latent factors.

The intrinsic interest of factor analysis is in the "underlying factors". The factor analysis model can be expressed in matrix notation:

Where

$$
x=\mu+\Lambda f+U
$$

$x$ : whether biodigester economically viable

$\Lambda:\{\lambda i j\}$ is a $p \times k$ matrix of constants, called the matrix of factor loadings.

$f$ : random vector representing the $\mathrm{k}$ common factors.

$U$ : random vector representing $p$ unique factors associated with the original variables.

Equation (1) can be used to find linear combinations of variables to explain set of observations of many variables used in the study. This equation extracts influential common factors that make the biodigester economically viable. A factor can be estimated as a linear combination of the original variables as:

$$
\widehat{F}_{j k}=\sum_{i=1}^{p} W_{j i} X_{i k}
$$

where $X_{i k}$ is the standardized value of the $\mathrm{i}^{\text {th }}$ variable for case $\mathrm{k}$ and $W_{j i}$ is the factor score coefficient for the $\mathrm{j}^{\text {th }}$ factor and the $\mathrm{i}^{\text {th }}$ variable.

One part of the output from a factor analysis is a matrix of factor loadings. A decision needs to be made regarding what constitutes a significant loading. A rule of thumb frequently used is that the absolute value of a factor loading greater than 0.3 is considered significant, greater than 0.4 is more important and greater than 0.5 is very important (Lawley \& Maxwell, 1971). Thus, rotated factor loadings greater than 0.4 are bold underlined to assist the interpretation of the meanings of the factors. Factor analysis was used to establish the correlation between 12 observed variables of whether biogas become economically viable or not. The number of factor components (FCs) extracted was based on criterion by Kaiser (1960) where the FC(s) with eigen values greater than 1 were considered. The variables produced unrelated components with eigen values greater than 1, all cumulatively accounting for $72 \%$ of the variance of the data set. 
Factor analysis extracted four factors each with eigen value greater than 1 (Table 8). For economically viable biodigester, the first factor was loaded on the observed variables "biodigester size", "No. of cookstoves per biodigester" and "No. of households per biodigester". The subset of observed variables loaded on the first factor are related to the capacity of biodigester and thus the first factor can be named as "biodigester capacity". The second factor is loaded on the subset of observed variables: "substrates feed with biodigester", "No. of cattle owned by adopter's household" and "No. of poultry owned by adopter's household". The subset of observed variables constituted the second factor was related to "easy access to substrates" and thus the second factor for the economic viability of biodigester is "availability and easy access to substrates" for feeding biodigester. The third factor is loaded on the subset of observed variables: "Amount of initial investment", "Annual maintenance cost" and "Source of substrates". The subset of observed variables constituted the third factor was related to "Amount of Investment for Biodigester" and thus the second factor for the economic viability of biodigester is "amount of investment for biodigester". The fourth factor is loaded on the subset of observed variables: "Operation life time of biodigester", "Monthly income from selling surplus gas" and "Income from bio-slurry". The subset of observed variables constituted the fourth factor was related to "Economic benefit derived from biodigester" and thus the second factor for the economic viability of biodigester is "Economic benefit derived from biodigester".

Table 8. Rotated component matrix of the selected characteristics

\begin{tabular}{|c|c|c|c|c|c|}
\hline \multirow[t]{2}{*}{ Observed Variables } & \multicolumn{4}{|c|}{ Extracted Factors } & \multirow[t]{2}{*}{ Communalities } \\
\hline & Factor 1 & Factor 2 & Factor 3 & Factor 4 & \\
\hline Digester size & $\underline{0.920}$ & 0.040 & -0.091 & -0.025 & 0.857 \\
\hline Amount of initial investment & $\overline{0.355}$ & 0.351 & $\underline{0.407}$ & 0.197 & 0.453 \\
\hline Annual maintenance cost & 0.079 & -0.014 & $\overline{0.771}$ & 0.000 & 0.601 \\
\hline Operation life time of biodigester & -.062 & -0.087 & $-\overline{-0.233}$ & $\underline{-0.689}$ & 0.541 \\
\hline No. of cookstoves per digester & $\underline{0.958}$ & 0.115 & 0.148 & $\overline{0.047}$ & 0.955 \\
\hline Substrates feed to biodigester & $\overline{0.009}$ & $\underline{0.901}$ & 0.025 & -0.015 & 0.813 \\
\hline Source of substrates & 0.031 & $\overline{-0.044}$ & $\underline{0.742}$ & 0.038 & 0.555 \\
\hline No. of cattle owned by household & -0.170 & $\underline{0.827}$ & $\overline{-0.002}$ & 0.040 & 0.715 \\
\hline $\begin{array}{l}\text { No. of poultry owned by } \\
\text { household }\end{array}$ & -0.008 & $\overline{0.869}$ & -0.066 & -0.008 & 0.760 \\
\hline No. of households per biodigester & $\underline{0.969}$ & 0.098 & 0.127 & 0.045 & 0.966 \\
\hline Monthly income from biogas & $\overline{0.105}$ & 0.015 & 0.198 & $\underline{0.860}$ & 0.789 \\
\hline Monthly income from bio-slurry & 0.034 & -0.088 & -0.138 & $\underline{0.813}$ & 0.688 \\
\hline Eigen value & 4.451 & 1.753 & 1.397 & 1.095 & \\
\hline Percent of variance & 37.088 & 14.606 & 11.642 & 9.124 & \\
\hline Cumulative variance (\%) & 37.088 & 51.695 & 63.337 & 72.461 & \\
\hline Bartlett's Test(Approx. $\chi^{2}$ ) & $2706.981^{* * *}$ & & & & \\
\hline $\begin{array}{l}\text { Kaiser-Meyer-Olkin Measure of } \\
\text { Sampling Adequacy. }\end{array}$ & 0.779 & & & & \\
\hline
\end{tabular}

\section{Conclusion}

Anaerobic digestion is a renewable energy source which can comfortably replace fossil fuel as an environment friendly process. The increasing demand for renewable energy compels the exploration of the increasing installation biogas digester especially in developing countries like Bangladesh. Biogas production addresses both waste reduction and energy production. High potential feedstock for biogas production, cow dung and poultry droppings, are readily available in own households in rural areas of Bangladesh. It is feasible to produce biogas from animal manure with simple equipment and a straight forward procedure. Even women family members can maintain the biogas digesters in Bangladesh involving no cash maintenance and operation costs. Biogas digester adaptors are satisfied with the performance of their biogas digester. Initial investment for the construction of biodigester is affordable and cheap. After meeting biodigester adopter's household need for cooking, some adopters can sell surplus biogas to earn money. Moreover, the process of biogas production is not merely source of energy, but also used as source of organic fertilizer for the own agricultural field and for earning additional money from selling surplus bio-slurry. Biodigester adopters are satisfied with performance of biodigester. Thus, Bangladesh is an ideal place to adopt biodigester for generating domestic biogas. Generation of biogas will meet the increasing demand of energy mainly for cooking and lighting. Thus, biogas generation through $\mathrm{AD}$ provides a valuable gas for cooking, better livelihoods in rural areas through health 
benefit, income generation from surplus time and selling surplus gas and bio-slurry after consumption, earning foreign currency from carbon trading etc. The economic viability of biogas generation depends on capacity of biodigester, availability and easy access to substrates, amount of investment for biodigester, and economic benefits derived from biodigester. Biogas production from various wastes through anerobic digestion technology is growing worldwide and is considered ideal in many ways due to its economic and environmental benefits. In Bangladesh, the use of cow dung and poultry droppings for biogas generation is well established. However, the costs of only cow dung or poultry dropping digesters are not favorable due to their relatively low biogas yield in comparison with co-digestion with kitchen wastes. More research is needed to find the appropriate combination of available substrates to use co-digesting technology. Successful implementation of anaerobic digestion as a method of waste treatment has the potential to change the concept waste into that of a valuable resource which will lead to total utilization of renewable energy resources reducing energy requirement, creating more jobs and income, reducing costs, making it readily available and minimize environmental pollution.

\section{Acknowledgement}

The authors received no specific funding for this work. The authors are grateful to the students of the faculty of business of Bangladesh University of Business and Technology and the students of the Department of Statistics, Jahangirnagar University, Bangladesh who helped in collecting data from the selected fields.

\section{References}

Abebe, M. A. (2017). Characterization of Fruit and Vegetable Waste with Cow Dung for Maximizing the Biogas Yield. International Journal of Scientific Engineering and Science, $1(1), 26-32$. http://ijses.com/wp-content/uploads/2017/02/119-IJSES-V1N1.pdf

Amigun, B., Parawira, W., Musango, J. K., Aboyade, A. O., \& Badmos, A. S. (2012). Anaerobic Biogas Generation for Rural Area Energy Provision in Africa. In kumar, S. (ed) Biogas. https://doi.org/10.5772/32630

Aragaw, T., Andargie, M., \& Gessesse, A. (2013). Co-digestion of cattle manure with organic kitchen waste to increase biogas production using rumen fluid as inoculums. International Journal of Physical Science, 8, 443-450. https://doi.org/10.5897/IJPS2013.3863

Bahauddin, K. M., \& Salahuddin, T. M. (2012). Prospect and Trend of Renewable Energy and its Technology Towards Climate Change Mitigation and Sustainable Development in Bangladesh. International Journal of Advanced Renewable Energy Research, 1(3), 156-166. http://www.ijarer.org/Issue.3/1-3-2.pdf

Bajgain, S., \& Shakya, I. (2005). In M.S. Mendis (ed.), The Nepal Biogas Support Program: A Successful Model of Public Private Partnerships for Rural Household Energy Supply. Kathmandu: MoFa Netherlands, SNV, BSP Nepal. http://energypedia.info/images/9/91/

Bailis, R., Drigo, R., Ghilardi, A., \& Masera, O. (2015). The carbon Footprint of Traditional Woodfuels. Nature Climate Change. Macmillan Publishers Limited. https://doi.org/10.1038/nclimate2491

Bond, T., \& Templeton, M. R. (2011). History and Future of Domestic Biogas plants in the Developing World. Energy for Sustainable Development, 15, 347-354. https://doi.org/10.1016/j.esd.2011.09.003

Chen, L., Zhao, L., Ren, C., \& Wang, F. (2012). The Progress and Prospects of Rural Biogas Production in China. Energy Policy, 51, 58-63. https://doi.org/10.1016/j.enpol.2012.05.052

Clements, J., Trimborn, M., Welland, P., \& Amon, B. (2006). Mitigation of Greenhouse Gas Emission by Anaerobic Digestion of Cattle Slurry. Agricultural, Ecosystems, and Environment, 112(2), 171-177. https://doi.org/10.1016/j.agee.2005.08.016

Clemens, H., Bailis, R., Nyambane, A., \& Ndung'u, V. (2018). Africa Biogas Partnership Program: A Review of Clean Cooking Implementation through Market Development in East Africa. Energy for Sustainable Development, 46, 23-31. https://doi.org/10.1016/j.esd.2018.05.012

Corro, G., Paniagua, L., Pal, U., Banelos, F., \& Rosas, M. (2013). Generation of biogas from coffee-pulp and cow-dung co-digestion: Infrared Studies of Post combustion Emissions. Energy Conversion and Management, 74, 471-481. https://doi.org/10.1016/j.enconman.2013.07.017

Das, A. K., Sahoo, S. K., \& Rana, S. K. (2018). Sustainable Conservation of Kitchen Wastes into Fuels and Organic Fertilizer. International Journal of Engineering Sciences \& Research Technology, 7(5), 503-510.

das Neves, L. C. M., Converti, A., \& Penna, T. C. V. (2009). Biogas Production: New Trends for Alternative Energy Sources in Rural and Urban Zones. Chemical Engineering Technology, 32, 1147-1153. https://doi.org/10.1002/ceat.200900051 
Donald, L. (1998). Biomass for Renewable Energy, Fuels and Chemicals. Academic Press.

EFC, (2012). Carbon Programs: Cameroon. http://www.envirofit.org/images/carbon/carbon_program_cameroon.pdf.

FAO, (1996). Biogas Technology: A Training Manual for Extension. http://www.fao.org/docrep/008/ae897e/ae897e00.HTM

Gautam, R., Baral, S., \& Herat, S. (2009). Biogas as a Sustainable Energy Source in Nepal: Present Status and Future Challenges. Renewable and Sustainable Energy Reviews, 13, 248-252. https://doi.org/10.1016/j.rser.2007.07.006

GEC (2012). Cookstove smoke is "largest environmental threat," Global Health Study finds. http:/energyblog.nationalgeographic.com/2012/12/13/cookstove-smoke-is-largest-environmental-threat-global-heat h-study-finds.

Ghimire, P. C. (2013). SNV Supported Domestic Biogas Programmes in Asia and Africa. Renewable Energy, 49, 90-94. https://doi.org/10.1016/j.renene.2012.01.058

Goffar, M. A. (2007). The Role of Grameen Shakti in Biogas Program in Bangladesh. A Concept Paper on Biogas, Biogas Extension Program, Organized by Grameen Shakti, Dhaka, 2006, Bangladesh.

Greben, H. A., \& Oelofse, S. H. H. (2009). Unlock the Resource Potential of Organic Waste: A South African Perspective. Waste Management and Research, 27, 676-684. https://doi.org/10.1177/0734242X09103817

Hasan, A. S. M. M., \& Ammenberg, J. (2019). Biogas potential from municipal and agricultural residual biomass for power generation in Hazaribagh, Bangladesh-A strategy to improve the energy system. Renewal Energy Focus, 29, 14-23. https://doi.org/10.1016/j.ref.2019.02.001

Hosseinpour, S., Hosseini, S. A. H. S. M., Mehdipour, R., Hemmasi, A. H., \& Ali, H. (2020). Energy Modeling and Techno-Economic Analysis of a Biomass Gasification-CHAT-ST Power Cycle for Sustainable Approach in Modern Electricity Grids. Journal of Renewable Energy and Environment, 7(2), 43-51. http://www.jree.ir/article_106780_87c6c513308810fdd757d6346c7db5b8.pdf

Huang, H., Khanna, M., Onal, H., \& Chen, X. (2013). Stacking low Carbon Policies on the Renewable Fuels Standard: Economic and Greenhouse Gas Implications. Energy Policy, 56, 5-15. https://doi.org/10.1016/j.enpol.2012.06.002

IHME. (2017). Findings from the Global Burden of Disease Study 2017. World Health Organization.

IRENA. (2017). Biogas for domestic cooking: Technology brief. IRENA. http://irena.org.///media/Files/IRENA/Agency/Publication/2017/Dec/IRENA. Biogas from domestic cooking 2017.pdf.

Jabeen, G., Yan, Q., Ahmad, M., Fatima, N., Jabeen, M., Li, H., \& Qamar, S. (2020). Household-based critical influence factors of biogas generation technology utilization: A case of Punjab province of Pakistan. Renewable Energy, 154, 650-660. https://doi.org/10.1016/j.renene.2020.03.049

Jones, P. (2010). Modelling the Commercial Profitability of AD Energy Production at the Farm Level within Arable and Diary Systems. http://www.ad4rd.soton.ac.uk/publications/Farm_AD_finalreport.pdf.

Kaiser, H. F. (1961). A Note on Guttman's Lower Bound for the Number of Common Factors. British Journal of Mathematical and Statistical Phycology. https://doi.org/10.1111/j.2044-8317.1961.tb00061.x

Kandapal, C., Joshi, B., \& Singh, C. S. (1991). Economics of Family Sized Biogas Plants in India. Energy Conservation Management, 32(2), 101-113. https://doi.org/10.1016/0196-8904(91)90150-H

Karki, A. B., Gautam, K. M., \& Karki, A. (1994). Biogas Installation from Elephant Dung at Machan Wildlife Resort, Chitwan, Nepal. Biogas Newsletter, Issue No. 45.

Kabir, H., Palash, M. S., \& Bauer, S. (2012). Appraisal of Domestic Biogas Plants in Bangladesh. Bangladesh Journal of Agricultural Economics, $X X X V(1 \& 2), 71-89$.

Kiran, E. U., Trzcinsk, A. P., Ng, W. J., \& Liu, Y. (2014). Bioconversion of Food Waste to Energy: A Review. Fuel, 134, 389-399. https://doi.org/10.1016/j.fuel.2014.05.074

Lawley, D. N., \& Maxwell, A. E. (1971). Factor Analysis as a Statistical Method. Second Edition, London, Butterworths.

Li, Y., Achinas, S., Zhao, J., Geurkink, B., Krooneman, J., \& Euverink, G. J. W. (2020). Co-digestion of cow and sheep manure: Performance evaluation and relative microbial activity. Renewable Energy, 153, 553-563. https://doi.org/10.1016/j.renene.2020.02.041

McCarl, B. A. (2010). Analysis of Climate Change Implications for Agriculture and Forestry: an Interdisciplinary Effect. 
Climate Change, 100(1), 119-124. https://doi.org/10.1007/s10584-010-9833-6

Mel, M., Yong, A. S. H., Avicenna, I. S. I., \& Setyobudi, R. H. (2015). Simulation Study for Economic Analysis of Biogas Production from Agricultural Biomass. Energy Procedia, 65, 204-214. https://doi.org/10.1016/j.egypro.2015.01.026

Moller, H. B., Sommer, S. G., \& Ahring, B. K. (2004). Biological Degradation and Greenhouse Gas Emission During Pre-storage of Liquid Animal Manure. Journal of Environmental Quality, 33(1), 27-36. https://doi.org/10.2134/jeq2004.2700

Moustakasa, K., Rehanb, M., Loizidoua, M., Nizamic, A. S., \& Naqvi, M. (2020). Energy and resource recovery through integrated sustainable waste management. Applied Energy, 261, 114-372. https://doi.org/10.1016/j.apenergy.2019.114372

Mwirigi, J., Balana, B. B., Mugisha, J., Walekhwa, P., Melamu, R., \& Nakami, S. et al. (2014). Socio-economic hurdles to widespread adoption of small-scale biogas digester in Sub-Saharan Africa: A Review. Biogas Bioenergy, 70(Supplement C), 17-25. https://doi.org/10.1016/j. biombio.2014.02.018

Nes, W. J. V., Boers, W., \& Khurshed-Ul-Islam. (2005). Feasibility National Programme on Domestic Biogas in Bangladesh. Netherlands Development Organization. Biogas Practice Team.

Nes, W. van \& Nhete, T. D. (2007). Biogas for Better Life-An African Initiatives. Renewal Energy World. https://www.renewableenergyworld.com/articles/print/volume-10/issue-4/bioenergy/biogas-for-a-better-life-an-afri can-initiative-51480.html.

Otun, T. F., Ojo, O. M., Ajibade, F. O., \& Babatola, J. O. (2015). Evaluation of Biogas Production from the Digestion and Co-digestion of Animal Waste, Food Waste and Fruit Waste. International Journal of Energy and Environmental Research, 3(3), 12-24.

Parawira, W. (2009). Biogas Technology in Sub-Saharan Africa: Status, Prospects and Constraints. Reviews in Environmental Science Bio/Technology, 8, 187-200. https://doi.org/10.1007/s11157-009-9148-0

Pei-dong, Z., Guomei, J., \& Gang, W. (2007). Contribution to Emission Reduction of CO2 and SO2 by household biogas construction in rural China. Renewable \& Sustainable Energy Reviews, 11, 1903-12. https://doi.org/10.1016/j.rser.2005.11.009

Putti, V. R., Tsan, M., Mehta, S., \& Kammila, S. (2015). The State of the Global Clean and Imporved Cooking Sector. ESMAP technical paper: No. 007/15 Washington, DC; World Bank. http://openknowledge.worldbank.prg/handle/10986/21878.

Rahman, K. M., Melville, L., Edwards, D. J., Fulford, D., \& Thwala, W. D. (2019). Determination of the Potential Impact of Domestic Anaerobic Digester Systems: A Community Based Research Initiative in Rural Bangladesh. Process, 7, 512. https://doi:10.3390/pr7080512

REN21 Secretariat, (2013). Renewable Energy Policy Network for the $21^{\text {st }}$ century (REN21). Renewables Global Status report: 2013 Update Report No. 177.

Risberg, K., Sun, L., Levén, L., Horn, S. I., \& Achnürer, A. (2013). Biogas Production from Wheat Straw and Manure-Impact of Pretreatment and Process Operating Parameters. Bioresource Technology, 149, 232-237. https://doi.org/10.1016/j.biortech.2013.09.054

Sagagi, B. S., Garbu, B., \& Usman, N. (2009), Studies on Biogas Production from Fruits and Vegetable Waste. Bayero Journal of Pure and Applied Science, 2(1), 115-118. https://doi: 10.4314/bajopas.v2i1.58513

Saroj, R. (2012). Marketing Energy Markets work for the poor: Large-scale dissemination of biogas plants in Nepal. Towards an "Energy Plus" approach for the Poor: A review of Good Practices and Lessons Learned from Asia and the Pacific. $\quad$ UNDP. $\quad$ Case 4 Study http://www.np.undp.org/content/nepal/en/home/library/aid/cordination/marketing-energy-markets-work-for-the-po or-large-scale-dissemination-of-biogas-plants-in-nepal-html.

Samira, S., Parveen, R., Salam, S., \& Azad, S. M. N. (2020). Feasibility Study for Biogas Generation from Household Digesters in Bangladesh: Evidence from a Household Level Survey. International Journal of Energy Economics and Policy, 10(4), 23-30. https://doi.org/10.32479/ijeep.9206

Salma A. I., Rahman, S., \& Yousuf, A. (2014). Present Scenario of Biogas Technology in Bangladesh-Prospects, Potential and Barriers. Proceedings of the $15^{\text {th }}$ Annual Paper Meet, Mechanical Engineering Division, The Institution of Engineers, Bangladesh. 
Shahrul, I. M., Hassan, M. F., Mamun, M. A. A., \& Malek, A. B. M. A. (2007). Prospect of Biogas Plant in the Rural Area of Bangladesh. Engineering e-Transaction, 2(2), 31-37.

Silva-Martínez, R. D., Sanches-Pereira, A., Ortiz, W., Galindo, M. G., \& Coelho, S. T. (2020). The state-of-the-art of organic waste to energy in Latin America and the Caribbean: Challenges and opportunities. Renewable Energy, 156, 509-525. https://doi.org/10.1016/j.renene.2020.04.056

Surendra, K. C., Takara, D., Hasimoto, A. G., \& Khanal, S. K. (2014). Biogas as a Sustainable Energy Source for Developing Countries: Opportunities and Challenges. Renewable and Sustainable Energy Reviews, 31, 846-859. https://doi.org/10.1016/j.rser.2013.12.015

Sunset, S. M., \& Gerrit, K. (2017). Potential from Domestic Biogas as Household Energy Supply in South Africa. Journal of Energy in Southern Africa, 28(2), 1-13, http://dx.doi.org/10.17159/2413-3051/2017/v28i2a1754.

Suntrace

(2018).

Solar

Market

Brief. https://suntrace.de/fieadmin/user_upload/Suntrac_Solar_Market_Brief_Bangladesh.pdf

UN FAO (2013). FAOSTAT Forestry Production and Trade. http://faostat3.fao.org/faostat-gateway/go/to/download/F/*/E.

UN (2015a). Ensure access to affordable, reliable, sustainable and modern energy. https://www.un.org/sustainabledevelopment/energy.

UN (2015b). Progress Toward https://sustainabledevelopment.un.org/content/documents/1699Progress\%20Toward\%20Sustainable\%20Energy\%2 0-\%20Global\%20Tracking\%20Framework\%202015\%20-\%20Key\%20Findings.pdf.

USDA (2014). Biogas Opportunities Roadmap: Voluntary Actions to Reduce Methane Emissions and Increase Energy Independence. U.S. Department of Agriculture, U.S. Environmental Protection Agency, U.S. Department of Energy.

Uzodinma, E. O., Ofoefule, A. U., Eze, J. J., \& Onwuka, N. D. (2007). Biogas Production from Belnds of Agro Industrial Waste. Trends of Applied Science Research, 2(6), 554-558. https://doi.10.3923/tasr.2007.554.558

Van Nes, J., \& Nhete, T. D. (2007). Biogas for the Better Life: An African Initiative. Appropriate Technology, 34(4), $58-62$.

Venkata, R. P., Michael, T., Sumi, M., \& Srilata, K. (2015). The State of the Global Clean and Improved Cooking Sector. ESMAP, GACC and World Bank. https://openknowledge.worldbank.org/bitstream/handle/10986/21878/96499.pdf?sequence=1\&isAllowed=y.

Von Eije, S. (2012). Financial and Economic Performance of Domestic Biogas Installations: Not Making Mooney, Still Getting Rich? Training Program on Compact Biogas Course During 10-13 April, 2012 in PPRE, Oldenburg University, Germany.

Walekhwa, P. N., Mugisha, J., \& Drake, L. (2009). Biogas Energy from Family Sized Digesters in Uganda: Critical Factors and Policy Implications. Energy Policy, 37, 2754-92. https://doi.org/10.1016/j.enpol.2009.03.018

Wang, X., Lu, X., Yang, G., Feng, Y., Ren, G., \& Han, X. (2016). Development Process and Probable Future Transformations of Rural Biogas in China. Renewable and Sustainable Energy Reviews, 55, 703-712. https://doi.org/10.1016/j.rser.2015.09.097

Weiland, P. (2010). Biogas production: current state and perspectives. Applied Microbiology and Biotechnology, 85, 849-860. https://doi.org/10.1007/s00253-009-2246-7

WHO (2016). Clean Household Energy for Health, Sustainable Development, and Wellbeing of Women and Children. http://apps.who.int/iris/bitstream/10665/204717/1/9789241565233_eng.pdf?uu=1

Zahariev, A., Penkov, D., \& Aladjadjiyan, A. (2014). Biogas from Animal Manure-Perspectives and Barriers in Bulgaria. Annual Research Review in Biology, 4(5), 709-719. https://doi.org/10.9734/ARRB/2014/6505

\section{Copyrights}

Copyright for this article is retained by the author(s), with first publication rights granted to the journal.

This is an open-access article distributed under the terms and conditions of the Creative Commons Attribution license which permits unrestricted use, distribution, and reproduction in any medium, provided the original work is properly cited. 